\title{
MOTIVASI, KOMUNIKASI, DAN LINGKUNGAN KERJA BERPENGARUH TERHADAP SEMANGAT KERJA GURU DI SMP NEGERI 5 DENPASAR
}

\author{
Ni Made Ariesta Yuna Pratiwi ${ }^{1}$ \\ I Gusti Salit Ketut Netra ${ }^{2}$ \\ ${ }^{1,2}$ Fakultas Ekonomi dan Bisnis Universitas Udayana (Unud), Bali, Indonesia \\ email: madeariesta98@yahoo.com
}

\begin{abstract}
ABSTRAK
Semangat kerja adalah sikap mental dari individu maupun kelompok yang mampu menciptakan suasana kerja, mendorong untuk bekerja sama, dan dapat menyelesaikan tugas tepat pada waktunya. Untuk meningkatkan semangat kerja perlu memperhatikan faktorfaktor yang mempengaruhinya. Tujuan penelitian ini adalah untuk mengetahui pengaruh motivasi, komunikasi, dan lingkungan kerja terhadap semangat kerja. Penelitian ini dilakukan di SMP Negeri 5 Denpasar. Jumlah populasi yang digunakan sebanyak 56 orang guru, karena jumlah sampel tergolong kecil sehingga metode yang digunakan yaitu metode sampling jenuh. Pengumpulan data dilakukan melalui wawancara dan kuesioner. Teknik analisis yang digunakan adalah regresi linier berganda. Berdasarkan hasil analisis menunjukkan bahwa motivasi, komunikasi, dan lingkungan kerja berpengaruh positif dan signifikan terhadap semangat kerja guru. Pihak SMP Negeri 5 Denpasar diharapkan lebih meningkatkan penjagaan kesehatan, memperhatikan komunikasi sesama guru, dan penataan ruangan agar guru merasa nyaman dalam bekerja.

Kata kunci : motivasi, komunikasi, lingkungan kerja, semangat kerja.
\end{abstract}

\begin{abstract}
Work morale is the mental attitude of individuals and groups that are able to create work atmosphere, encourage cooperation, and can complete tasks on time. To increase morale, it is necessary to pay attention to the factors that influence it. The purpose of this study was to determine the effect of motivation, communication, and work environment on work morale. This research was conducted at SMP Negeri 5 Denpasar. 56 teachers are used as sampleswith saturated sampling method. Data collection collected by interviews and questionnaires. The analysis technique used is multiple linear regression. Motivation, communication, and work environment have positive and significant effect on teacher morale. SMP Negeri 5 Denpasar is expected to further improve health care, pay attention to the communication of fellow teachers, and arrange the room so that teachers feel comfortable in working.
\end{abstract}

Keywords: motivation, communication, work environment, work morale 


\section{PENDAHULUAN}

Sumber daya manusia adalah harta atau aset yang paling berharga dan paling penting dimiliki oleh suatu organisasi, karena keberhasilan organisasi sangat ditentukan oleh unsur manusia (Syamsuri, 2017). Peran sumber daya manusia dalam organisasi adalah modal dasar dimana semangat kerja karyawan sangat menentukan maju atau mundurnya suatu organisasi (Darmawan \& Wibawa, 2019). Guru sebagai salah satu unsur dalam proses belajar mengajar sangat berperan penting, baik sebagai pengajar yang melakukan transfer of knowledge, dan dapat juga sebagai pembimbing yang mendorong potensi, mengembangkan, dan memobilisasi siswa dalam belajar (Karademir et al., 2016). Guru sebagai pengajar atau pendidik adalah hal yang perlu diperhatikan agar bisa menyampaikan suatu pengajaran dengan baik didalam menyampaikan proses pembelajaran di kelas dan puas dengan hasil yang di capai siswa. Keberadaan guru sangatlah penting dalam mencapai terwujudnya visi dan misi serta tujuan pembelajaran dimana guru tersebut melaksanakan tugasnya sebagai seorang guru.

Semangat kerja guru sangat diperlukan dalam dunia pendidikan. Dengan adanya semangat kerja, merangsang guru untuk lebih baik dan mempunyai daya kreativitas yang tinggi dalam bekerja, dalam mencapai tujuan yang jamak tidak hanya tujuan pendidikan nasional pada umumnya, namun juga tujuan individu. Dengan meningkatnya semangat kerja maka pekerjaan akan lebih cepat terselesaikan, absensi dapat dikurangi, kerusakan barang akan dapat dikurangi dan kemungkinan perpindahan karyawan dapat diperkecil (Tiwari, 2015). Arunchand \& Ramanathan (2016) menyatakan semangat kerja pegawai adalah hubungan yang dimiliki pegawai atau sekelompok pegawai tertentu dengan pekerjaan mereka dan organisasi tempat mereka bekerja, semangat kerjapegawai yang tinggi berarti pegawai senang, dan itu tercermin dalam jenis pekerjaan mereka hasilkan. Semangat kerja memiliki peran penting dalam menentukan kecepatan dan kualitas hasil pekerjaan karyawan. Semangat kerja adalah melakukan pekerjaan secara lebih giat sehingga dengan demikian pekerjaan akan dapat diharapkan lebih cepat dan lebih baik (Widani, 2018).

Sekolah Menengah Pertama (SMP) Negeri 5 Denpasar merupakan institusi pendidikan negeri yang sudah ada sejak tahun 1979 dan pada tahun 2019 ini telah berusia 40 tahun. Sekolah yang terletak di daerah Denpasar Utara ini memiliki banyak guru, pegawai dan siswa. Dengan total guru tetap (PNS) 40 orang, guru honorer sebanyak 16 orang, 15 orang pegawai tidak tetap, dan 3 orang pegawai tetap. Semangat kerja guru di SMP Negeri 5 Denpasar terlihat masih rendah, hal tersebut dilihat dari hasil wawancara awal terhadap 10 orang guru. Hasil wawancara awal cenderung berada pada skor tidak setuju, yang mengindikasikan semangat kerja yang rendah dan perlu diketahui penyebabnya berdasarkan indikator-indikator yang sesuai.

Berdasarkan wawancara tidak terstruktur terhadap kepala sekolahmengenai semangat kerja dikatakan bahwa terdapat permasalahan yaitu mengenai motivasi pada organisasi ini masih adanya guru dan pegawai yang melanggar peraturan seperti meninggalkan sekolah pada saat jam mengajar berlangsung, banyaknya guru yang datang terlambat, tidak berada diruangan 
dalam rangka memberikan pelayanan dan melaksanakan pekerjaan sesuaidengan deskripsi kerja guru masing-masing. Selain itu komunikasi yang terjadidalam organisasi ini masih kurang efektif, seperti kurangnya berinteraksi dan berkoordinasi terhadap sesama guru terkait dengan pembagian tugas dalam sekolah. Koordinasi dan komunikasi antara guru mata pelajaran serumpun yang disebut dengan Musyawarah Guru Mata Pelajaran (MGMP) belum berjalan dengan baik. Sedangkan jadwal kegiatan MGMP di sekolah sudah disusun dan diterapkan oleh kepala sekolah.

Koordinasi dan komunikasi dalam implementasi tugas-tugas tambahan seperti kepanitiaan yang sudah ditetapkan melalui surat keputusan kepala sekolah juga belum dilaksanakan secara maksimal. Indikator ini terlihat dari pelaksanaan kegiatan-kegiatan dalam kepanitiaan tertentu masih perlu diingatkan oleh kepala sekolah. Begitu juga mengenai lingkungan kerja yang kurang nyaman seperti sering terjadinya kebisingan di ruang kerja dikarenakan lokasi sekolah yang berada di tepi jalan raya serta ditengah pemukiman warga. Semangat kerja dalam suatuorganisasi dipengaruhi oleh beberapa faktor. Faktor-faktor yang mepengaruhi semangat kerja berasal dari internal dan external pegawai. Faktorfaktor yang mempengaruhi semangat kerja meliputi kepemimpinan, motivasi, komunikasi, dan lingkungan kerja (Maduka \& Okafor, 2015). Guru dalam melakukan kegiatan umumnya didorong oleh adanya motivasi untuk menunjukkan kinerja yang baik. Motivasi merupakan faktor yang mempengaruhi semangat kerja (Omollo, 2015).

Menurut Sumampouw et al. (2016)motivasi merupakan faktor penting dalam meningkatkan semangat kerja karyawan. Motivasi akan mendorong karyawan untuk lebih tekun dan giat dalam melakukan pekerjaannya, tanpa motivasi, setiap karyawan belum tentu bersedia mengarahkan seluruh kemampuannya secara optimal (Mudasir et al., 2015). Ahmed et al. (2016) mengemukakan bahwa motivasi adalah usaha seseorang untuk mencapai suatu tujuan yang lebih baik. Untuk menumbuhkan semangat kerja tentunya motivasi menjadi salah satu faktor penimbang dalam pendorong semangat kerja. Motivasi mempengaruhi semangat kerja, apabila motivasi baik maka semangat kerja akan meningkat, begitu pula apabila motivasi tidak baik maka semangat kerja akan menurun (Octaviani \& Suana, 2019). Motivasi adalah bagaimana kekuatan dan potensi atasan mengarahkan guru untuk bekerja sama secara produktif dan berhasil mencapai tujuan yang telah ditetapkan (Riyanto et al., 2017). Dalam sistem motivasi terdiri atas tiga hal yang saling bergantung pada elemen kebutuhan, dorongan dan tujuan

Hal lain yang dapat mempengaruhi semangat kerja adalah komunikasi (Shonubi \& Akintaro, 2016). Komunikasi merupakan suatu proses melalui individu dengan organisasi dan masyarakat dalam menciptakan, mengirimkan dan menggunakan informasi untuk mengkoordinasi lingkungannya dan orang lain (Ololube, 2015). Devina \& Anu (2015) menyatakan komunikasi memainkan peran utama dalam meningkatkan kepuasan kerja karyawan dan kepuasan kerja karyawan akan membuat karyawan memiliki semangat kerja yang tinggi.

Lingkungan kerja merupakan faktor lain yang dapat mempengaruhi semangat kerja. Shidhaye et al. (2015) menyatakan bahwa lingkungan kerja 
memiliki pengaruh besar untuk seorang individu, yang akan memberikan efek besar pada apa yang dikerjakan. Jain \& Kaur (2016) menyatakan bahwa produktivitas guru ditentukan oleh tingkat lingkungan kerja disekitarnya dimana mereka bekerja yang melibatkan semua aspek. Maslichah \& Hidayat (2017) mendefinisikan lingkungan kerja sebagai suatu atau keseluruhan dari komponen-komponen yang berhubungan dengan suatu lembaga, organisasi, atau perusahaan yang memiliki suatu pola yang tidak lepas dari lingkungan dimana lembaga, organisasi, atau perusahaan itu berada. Menurut Swandono (2016) linkungan kerja yang kondusif dan nyaman akan mempengaruhi semangat kerja karyawan sehingga karyawan termotivasi untuk mencapai tujuan perusahaan. Lingkungan kerja merupakan segala sesuatu yang ada disekitar para pekerja yang dapat mempengaruhi dirinya dalam menjalankan tugas-tugas yang dikerjakan untuk meningkatkan kepuasan dan semangat kerja

Teori yang melandasi penelitian ini adalah teori dua faktor yang dikemukakan oleh Frederick Herzberg dalam Dewi \& Dewi (2019) menjelaskan bahwa terdapat dua faktor yaitu faktor intrinsik dan ekstrinsik yang mempengaruhi seseorang dalam bekerja. Faktor intrinsik yaitu (motivator) merupakan faktor yang kehadirannya dapat menimbulkan rasa gairah atau semangat karyawan dalam melakukan tugasnya sehingga dapat meningkatkan hasil kerja. Yang termasuk faktor ekstrinsik dapat dilihat dari hubungan interpersonal yaitu komunkasi yang terjalin antara sesama karyawan ataupun antara karyawan dengan atasannya. Selain hubungan interpersonal, kondisi pekejaan juga dapat dilihat dari penjagaan kesehatan dan fasilitas-fasilitas yang diberikan perusahaan. Hal ini berkaitan dengan komunikasi dan lingkungan kerja para karyawan yang berdampak pada semangat kerja karyawan (Ghaffari et al., 2017). Tanpa adanya kedua faktor ini dapat menimbulkan turunnya rasa gairahan karyawan dalam bekerja dana akan mempengaruhi tingkat kehadiran karyawan (Femi, 2014).

Putra \& Suwandana (2019) menyebutkan bahwa motivasi berpengaruh positif dan signifikan terhadap semangat kerja, yang berarti apabila motivasi semakin baik maka semangat kerja yang dimiliki pegawai Bappeda Litbang Provinsi Bali akan meningkat dan sebaliknya, semakin buruk motivasi maka semangat kerja yang dimiliki pegawai Bappeda Litbang Provinsi Bali akan menurun. Cahyani \& Mujiati (2019) menyatakan bahwa motivasi memiliki pengaruh positif dan signifikan terhadap semangat kerja, hal ini menunjukkan apabila motivasi semakin baik maka semangat kerja guru di SMP TamanSastra akan meningkat. Sumampouw et al. (2016), menyatakan bahwa motivasi memiliki pengaruh positif dan signifikan terhadap semangat kerjakaryawan pada PT. Bank Tabungan Negara, TBK.

Syamsudin \& Bachtiar (2018), mengungkapkan motivasi berpengaruh positif signifikan terhadap semangat kerja karyawanPT. Utama Gas Multi Perkasa Cabang Serang. Sementara penelitian Adnyani \& Surya (2019) mengemukakan bahwa motivasi berpengaruh positif dan signifikan terhadap semangat kerja di Bumdes Udaka Dawan. Artinya jika semakin tinggi motivasi yang dirasakan oleh karyawan maka semangat kerja karyawan juga akan meningkat. Berdasarkan 
hasil-hasil studi empiris tersebut maka dapat dirumuskan hipotesis pertama sebagai berikut.

$\mathrm{H}_{1}$ : Motivasi berpengaruh positif dan signifikan terhadap semangat kerja.

Penelitian yang dilakukan oleh Yasa \& Wibawa (2015) menyatakan bahwa komunikasi berpengaruh positif dan signifikan terhadap semangat kerja karyawan PT. Sang Tunas Sejahtera. Hal ini memiliki makna bahwa semakin intern komunikasi tersebut maka semakin meningkatkan semangat kerja. Jannah et al.(2018),Widani (2018) menunjukkan bahwa komunikasi berpengaruh positif dan signifikan terhadap semangat kerja. Penelitian yang dilakukan Arianto (2015) menyatakan bahwa komunikasi berpengaruh positif dan signifikan terhadap semangat kerja. Hal ini memiliki makna semakin intern komunikasi tersebut maka semakin meningkatkan semangat kerja. Utamajaya \& Ayu Sriathi (2015) menemukan bahwa komunikasi berpengaruh signifikan terhadapsemangat kerja karyawan dengan arah yang positif, semakin baik komunikasi yang dilakukan maka akan semakin meningkatkan semangat kerja. Berdasarkan hasil-hasil studi empiris tersebut maka dapat dirumuskan hipotesis kedua sebagai berikut.

$\mathrm{H}_{2}$ : Komunikasi berpengaruh positif dan signifikan terhadap semangat kerja.

Cahyani \& Mujiati (2019) menyebutkan lingkungan kerja berpengaruh positif dan signifikan terhadap semangat kerja. Hal ini berarti bahwa apabila lingkungan kerja semakin baik maka semangat kerja guru di SMP Taman Sastra akan meningkat dan sebaliknya, semakin buruk lingkungan kerja maka semangat kerja yang dimiliki guru di SMP Taman Sastra akan menurun. Penelitian oleh Fitri (2015) menyatakan bahwa lingkungan kerja berpengaruh positif dan signifikan terhadap semangat kerja karyawan pada Hotel Indrapura Pekanbaru.

Jayaet al. (2017) menyatakan bahwa lingkungan kerja berpengaruh positif dan signifikan terhadap semangat kerja. Hal ini memiliki makna bahwa untuk setiap peningkatan yang terjadi pada lingkungan kerja akan menimbulkan peningkatan pada semangat kerja. Inbar et al.(2018) dalam penelitiannya mengemukakan bahwa lingkungan kerja berpengaruh positif dan signifikan terhadap semangat kerja, artinya semakin baik lingkungan kerja maka semangat kerja karyawan juga semakin meningkat. Selain itu penelitian daari Hasanah \& Kasmiruddin (2016) menyatakan bahwa lingkungan kerja berpengaruh positif dan signifikan terhadap semangat kerja. Hal ini berarti semakin baik lingkungan kerja maka akan meningkatkan semangat kerja, ini berarti untuk dapat meningkatkan semangat kerja perusahaan haruslah memperhatikan betul lingkungan kerja disekitar perusahaan. Berdasarkan hasil-hasil studi empiris tersebut maka dapat dirumuskan hipotesis ketiga sebagai berikut.

$\mathrm{H}_{3}$ : Lingkungan kerja berpengaruh positif dan signifikan terhadap semangat kerja.

\section{METODE PENELITIAN}

Desain penelitian ini bersifat asosiatif. Penelitian ini dilakukan di SMP Negeri 5 Denpasar, yang berlokasi di Jalan Cokroaminoto Gang Angsoka, Ubung, 
Denpasar Utara, Bali. Lokasi ini dipilih karena keinginan peneliti untuk mengetahui motivasi, komunikasi, lingkungan kerja, dan semangat kerja yang ada di dalam organisasi tersebut.Obyek penelitian ini adalah motivasi, komunikasi, dan lingkungan kerja terhadap semangat kerja. Dalam penelitian ini variabel terikat adalah semangat kerja (Y).Variabel bebas dalam penelitian ini adalah motivasi, komunikasi, dan lingkungan kerja.

Dalam penelitian ini semangat kerja merupakan sikap mental dari seorang guru yang mampu menciptakan iklim atau suasana kerja yang dapat mendorong seorang guru untuk bekerja sama, dan bekerja lebih giat dalam mengejar tujuan bersama. Variabel semangat kerja dapat diukur dengan indikator sebagai berikut Febriani \& Supartha (2019) : 1) Tingkat kehadiran merupakan tingkat kehadiran guru yang menunjukkan tinggi rendahnya semangat kerja guru. Indikator ini diukur dari persepsi guru tentang jumlah atau tingkat kehadiran guru di dalam kelas sudah maksimal sesuai jam mengajar. 2) Pelaksanaan pekerjaan tepat waktu merupakan seluruh pekerjaan yang diselesaikan tepat pada waktunya oleh guru. Indikator ini diukur dari persepsi guru tentang menyelesaikan jam mengajar tepat waktunya sesuai dengan jawal. 3) Tidak meninggalkan tempat kerja pada waktu kerja merupakan tidak ada guru yang meninggalkan pekerjaan saat waktu kerja. Indikator ini diukur dari persepsi guru tentang tidak meninggalkan kelas saat jam mengajar berlangsung. 4) Pelaksanaan pekerjaan sesuai intruksi atasan (kepala sekolah) dimana guru selalu melakukan pekerjaan sesuai perintah atasan (kepala sekolah). Indikator ini diukur dari persepsi guru tentang melakukan proses belajar mengajar sesuai dengan instruksi pimpinan (kepala sekolah).5) Kepuasan terhadap pembagian tugas adalah rasa puas guru dalam pembagian tugas yang diberikan oleh pimpinan (kepala sekolah). Indikator ini diukur dari persepsi guru tentang kepuasan guru terhadap pembagian tugas yang diberikan oleh kepala sekolah.

Motivasi dalam penelitian ini yaitu tindakan atau dorongan untuk mempengaruhi sesama guru guna melaksanakan tugas dan kewajibannya yang dihadapi dalam mencapai tujuan yang diharapkan. Variabel motivasi dapat diukur dengan indikator sebagai berikut (Zahari, 2015): 1) Kebutuhan fisiologis merupakan kebutuhan yang diperlukan untuk mempertahankan kelangsungan hidup guru seperti makan, minum, udara,dan tempat tinggal. Indikator ini diukur dari persepsi guru tentang pendapatan yang diperoleh sudah mencukupi kebutuhan hidup. 2) Kebutuhan rasa aman dan perlindungan merupakan kebutuhan akan keamanan dari ancaman yakni merasa aman dari ancaman kecelakaan dan keselamatan dalam melakukan pekerjaan. Indikator ini diukur dari persepsi guru tentang rasa aman dalam bekerja. 3) Kebutuhan sosial merupakan kebutuhan guru sebagai makhluk sosial yang membutuhkan pergaulan dengan orang lain (rekan guru dan pegawai) dan untuk diterima sebagai bagian dari orang lain (rekanguru dan pegawai). Indikator ini diukur dari persepsi guru tentang keterlibatan dalam kegiatan yang diadakan oleh sekolah. 4) Kebutuhan penghargaan merupakan kebutuhan yang diperlukan oleh guru seperti penghargaan diri, pengakuan serta penghargaan prestasi dari rekan guru atas hasil pekerjaannya selama ini. Indikator ini diukur dari persepsi guru tentang penghargaan yang diberikan oleh kepala sekolah. 5) Kebutuhan aktualisasi diri 
merupakan kebutuhan yang diperlukan oleh guru dengan menggunakan kecakapan, kemampuan, keterampilan, dan potensi optimal untuk mencapai prestasi kerja yang memuaskan atau luar biasa yang sulit dicapai orang lain. Indikator ini diukur dari persepsi guru tentang kepala sekolah memberikan kesempatan pelatihan kepada guru untuk meningkatkan kompetensi.

Komunikasi dalam penelitian ini yaitu proses pemindahan suatu informasi, ide, dan pengertian dari guru kepada orang lain (guru, dan kepala sekolah) dengan harapan orang lain (guru, dan kepala sekolah) tersebut dapat menginterprestasikannya sesuai dengan tujuan yang dimaksud. Variabel komunikasi dapat diukur dengan menggunakan indikator sebagai berikut (Gresida \& Utama, 2019): 1) Diskusi kepala sekolah dengan guru mengenai masalah pekerjaan, artinya setiap masalah yang dihimpun oleh kepala sekolah selalu melibatkan guru dalam hal diskusi untuk penyelesaian. Indikator ini diukur dari persepsi guru tentang diskusi dengan kepala sekolah terkait masalah pekerjaan. 2) Koordinasi dengan guru lainnya dalam menyelesaikan masalah dalam pekerjaan, artinya setiap ditemukan permasalahan selalu melakukan diskusi dan informasi kepada guru lainnya. Indikator ini diukur dari persepsi guru tentang berkoordinasi dengan sesama guru terkait masalah yang ada. 3) Tegur sapa vertikal antara guru dengan kepala sekolah artinya dalam keseharian di tempat kerja kepala sekolah selalu melakukan tegur sapa kepada guru setiap bertemu yang dapat memupuk kebiasaan komunikasi sehingga apabila terjadi keluhan, permasalahan, dan ide positif. Indikator ini diukur dari persepsi guru tentang bertegur sapa kepada sesama guru di sekolah. 4) Kejelasan informasi mengenai pekerjan yang diberikan oleh kepala sekolah, artinya informasi yang diberikan oleh kepala sekolah jelas sehingga tugas yang diberikan oleh kepala sekolah sesuai dengan apa yang diinginkan oleh kepala sekolah. Indikator ini diukur dari persepsi guru tentang informasi yang diberikan terkait tugas-tugas yang diberikan oleh kepala sekolah sudah jelas. 5) Tugas yang diberikan kepala sekolah sesuai dengan kemampuan guru, artinya setiap tugas yang diberikan kepala sekolah sesuai dengan wewenang dan kemampuan guru dalam penyelesaiannya. Indikator ini diukur dari persepsi guru tentang tugas yang diberikan sesuai dengan kemampuan yang saya miliki.

Lingkungan kerja dalam penelitian ini adalah segala sesuatu yang ada di sekitar guru, yang dapat mempengaruhi seorang guru dalam menjalankan tugastugas yang diberikan. Variabel lingkungan kerja dapat diukur dengan indikator sebagai berikut (Nuraini et al., 2015): 1) Penerangan atau cahaya di tempat kerja (sekolah), Penerangan sangat penting bagi guru untuk meningkatkan keselamatan dan kelancaran dalam bekerja. Selain itu penerangan yang baik adalah penerangan yang cukup, tidak terlalu gelap dan tidak terlalu terang. Indikator ini diukur dari persepsi guru tentang suasana ruang kelas tempat mengajar yang nyaman. 2) Keadaan udara di tempat kerja (sekolah) harus berada pada tingkat yang optimal. Hal ini bisa ditingkatkan dengan cara menerapkan sistem ventilasi yang baik atau dengan memasang air conditioner. Indikator ini diukur dari persepsi guru tentang beradaptasi dengan suhu udara di sekolah. 3) Fasilitas kerja merupakan sesuatu yang terdapat di dalam sekolah yang dapat dinikmati dan digunakan oleh guru untuk kelancaran proses mengajarnya. Indikator ini diukur dari persepsi guru tentang fasilitas yang ada di ruang kelas lengkap. 4) Hubungan dengan sesama 
guru diharapkan baik dan selaras, sehingga dalam bekerja menjadi lebih semangat dan dapat menyelesaikan pekerjaan dengan cepat. Indikator ini diukur dari persepsi guru tentang hubungan kekrabatan dengan sesama rekan guru terjalin dengan baik. 5) Kemanan, Lingkungan kerja yang baik adalah lingkungan kerja yang aman dari kejahatan, radiasi, bencana, dan hal lain yang dapat membahayakan nyawa guru. Indikator ini diukur dari persepsi guru tentang kemanan (radiasi dari komputer, dan kemanan menaruh barang-barang berharga di sekolah seperti sepeda motor) .

Populasi penelitian ini adalah seluruh guru di SMP Negeri 5 Denpasar yang berjumlah sebanyak 56 guru. Teknik pengambilan sampel dilakukan dengan sampling jenuh, Untuk memperoleh data, penelitian ini menggunakan teknik pengumpulan data dengan menggunakan metode wawancara, dan kuesioner. Proses wawancara diawali dengan pengantar yaitu secara terbuka dan jujur memperkenalkan diri dan menjelaskan tujuan dari wawancara. Kuesioner dalam penelitian ini adalah tentang motivasi, komunikasi, dan lingkungan kerja serta semangat kerja dari organisasi.

Data kualitatif dalam penelitian ini adalah sejarah singkat, dan struktur organisasi sekolah serta jawaban responden berupa pernyataan mengenai seluruh variabel yang digunakan dalam kuesioner penelitian ini. Data kuantitatif dalam penelitian ini yaitu jumlah guru SMP Negeri 5 Denpasar, dan skor dari jawaban responden Sumber primer yang dikumpulkan dalam penelitian ini berasal dari responden penelitian yaitu guru SMP Negeri 5 Denpasar yang diperoleh melalui wawancara, dan menyebarkan kuesioner mengenai motivasi, komunikasi, lingkungan kerja, dan semangat kerja. Sumber sekunder dalam penelitian ini yaitu berupa jumlah guru, dan struktur organisasi sekolah.

\section{HASIL DAN PEMBAHASAN}

Sebelum menjadi SMP Negeri 5 Denpasar, pada awalnya merupakan Sekolah Kejuruan dengan nama SKKP Negeri Denpasar yang beralamat di Jalan Surapati Denpasar. Berdasarkan Surat Keputusan Menteri Pendidikan Dan Kebudayaan Republik Indonesia Nomor: 030/U/1979, Tanggal 17 Pebruari 1979, Tentang: Pelaksanaan Integrasi Sekolah Menengah Kejuruan Tingkat Pertama Menjadi Sekolah Menengah Umum Tingkat Pertama dari SKKP Negeri Denpasar berubah menjadi SMP Negeri V Denpasar dengan alamat di Jalan Surapati Denpasar.

Kemudian berdasarkan Surat Wali Kota Madya Denpasar Nomor: 300/5063/Org, Tanggal 21 September 1998, Hal: Permohonan Gedung SLTPN. 5 Denpasar yang ditujukan kepada Kepala Kantor Wilayah Departemen Pendidikan Dan Kebudayaan Provinsi Bali, terbitlah Surat Kakanwil Depdikbud Provinsi Bali Nomor: 1273/I 19. B/ tanggal 2 Oktober 1998 tentang Permohonan Gedung SLTPN. 5 Denpasar yang isinya bahwa mulai tahun ajaran 1996/1997 sebagian siswa SLTPN. 5 Denpasar (Kelas 1) sudah menempati Gedung Baru di Ubung, sedangkan untuk kelas II dan III masih menempati Gedung Lama di Jalan Surapati Denpasar. Berdasarkan informasi dari guru senior dan masyarakat Ubung yang menjadi Komite Sekolah, bahwa Gedung Baru yang ditempati oleh SMP 
Negeri 5 Denpasar mulai tahun 1996/1997 tersebut adalah Gedung milik SMP Widya Santi (Sekolah Swasta yang didirikan oleh Masyarakat Desa Ubung) dengan alamat Jalan Cokroaminoto, Gang Angsoka Ubung Denpasar, yang selanjutnya diserahkan kepada Pemerintah Kota Madya Denpasar.

Tabel 1.

Karakteristik Responden SMP Negeri 5 Denpasar Berdasarkan Jenis Kelamin, Usia, Dan Pendidikan Terakhir

\begin{tabular}{|c|c|c|}
\hline Keterangan & Jumlah (Orang) & Presentase (\%) \\
\hline \multicolumn{3}{|l|}{ Jenis Kelamin } \\
\hline Laki-laki & 20 & 35,71 \\
\hline Perempuan & 36 & 64,29 \\
\hline Total & 56 & 100 \\
\hline \multicolumn{3}{|l|}{ Usia } \\
\hline $21-30$ & 10 & 17,86 \\
\hline $31-40$ & 12 & 21,43 \\
\hline$>41$ & 34 & 60,71 \\
\hline Total & 56 & 100 \\
\hline \multicolumn{3}{|l|}{ Pendidikan Terakhir } \\
\hline $\mathrm{S} 2$ & 8 & 14,29 \\
\hline S1 & 46 & 82,14 \\
\hline DII & 2 & 3,57 \\
\hline Total & 56 & 100 \\
\hline
\end{tabular}

Tabel 1. menunjukkan terdapat tiga karakteristik responden yaitu jenis kelamin, usia, dan pendidikan terakhir. Penelitian ini didominasi dengan responden berjenis kelamin perempuan dengan presentase sebesar 64,29 persen, karena guru perempuan lebih lembut dan lebih sabar dalam mendidik siswa, sedangkan sisanya sebesar 35,71 persen berjenis kelamin laki-laki. Sebagian besar responden dalam penelitian ini berusia 41 tahun keatas dengan jumlah 34 orang dengan presentase 60,71 persen. Artinya semakin tinggi dan ketat persaingan dalam dunia kerja membuat guru lebih termotivasi untuk tetap bertahan di dalam organisasi. Pendidikan terakhir responden sebagian besar merupakan lulusan S1 khususnya dalam pendidikan guru dengan presentase 82,14 persen yang berjumlah 46 orang, sedangkan lulusan S2 sebanyak 8 orang (Kepala Sekolah, dan 7 orang guru) dengen presentase 14,29 persen, dan untuk lulusan diploma memiliki jumlah 2 orang dengan presentase 3,57 persen. Hal ini menunjukkan bahwa SMP Negeri 5 Denpasar memiliki guru dengan tingkat pendidikan yang baik, artinya bahwa semakin tinggi tingkat pendidikan guru maka wawasan yang dimiliki semakin luas, sehingga komunikasi antar rekan kerja akan terjalin dengan baik akan mampu menimbulkan semangat kerja.

Hasil uji validitas pada Tabel 2. menunjukan bahwa seluruh instrumen penelitian yang digunakan untuk mengukur variabel motivasi, komunikasi, lingkungan kerja dan semangat kerja memiliki nilai koefisien korelasi dengan skor total seluruh butir-butir pernyataan lebih besar dari 0,3. Hal ini menunjukan bahwa butir-butir pernyataan dalam instrumen penelitian tersebut valid dan layak digunakan sebagai instrumen penelitian. 
Tabel 2.

Hasil Uji Validitas

\begin{tabular}{|c|c|c|}
\hline Variabel & Indikator & Koefisien Korelasi \\
\hline \multirow{5}{*}{ Motivasi $\left(\mathrm{X}_{1}\right)$} & $\mathrm{X} 1.1$ & 0,815 \\
\hline & $\mathrm{X} 1.2$ & 0,751 \\
\hline & $\mathrm{X} 1.3$ & 0,871 \\
\hline & $\mathrm{X} 1.4$ & 0,830 \\
\hline & $\mathrm{X} 1.5$ & 0,891 \\
\hline \multirow[t]{5}{*}{ Komunikasi $\left(\mathrm{X}_{2}\right)$} & $\mathrm{X} 2.1$ & 0,770 \\
\hline & $\mathrm{X} 2.2$ & 0,920 \\
\hline & $\mathrm{X} 2.3$ & 0,826 \\
\hline & $\mathrm{X} 2.4$ & 0,725 \\
\hline & $\mathrm{X} 2.5$ & 0,813 \\
\hline \multirow[t]{5}{*}{ Lingkungan Kerja $\left(\mathrm{X}_{\Xi}\right)$} & $\mathrm{X} 3.1$ & 0,905 \\
\hline & $\mathrm{X} 3.2$ & 0,837 \\
\hline & $\mathrm{X} 3.3$ & 0,870 \\
\hline & $\mathrm{X} 3.4$ & 0,808 \\
\hline & $\mathrm{X} 3.5$ & 0,909 \\
\hline \multirow[t]{5}{*}{ Semangat Kerja (Y) } & $\mathrm{Y}_{.1}$ & 0,711 \\
\hline & $\mathrm{Y}_{.2}$ & 0,800 \\
\hline & $\mathrm{Y}_{.3}$ & 0,817 \\
\hline & $\mathrm{Y}_{.4}$ & 0,786 \\
\hline & $\mathrm{Y}_{.5}$ & 0,821 \\
\hline
\end{tabular}

Sumber: Data diolah, 2019

Hasil uji reliabilitas yang disajikan dalam Tabel 3. menunjukan bahwa seluruh instrumen penelitian memiliki koefisien cronbach's alpha lebih dari 0,60 . Hal ini dapat dinyatakan bahwa seluruh variabel telah memenuhi syarat reliabilitas sehingga dapat digunakan untuk melakukan penelitian.

Tabel 3.

Hasil Uji Reliabilitas

\begin{tabular}{|c|c|c|}
\hline No. & Variabel & Cronbach's Alpha \\
\hline 1 & Motivasi (X1) & 0,881 \\
\hline 2 & Komunikasi (X2) & 0,863 \\
\hline 3 & Lingkungan Kerja (X3) & 0,912 \\
\hline 4 & Semangat Kerja $(\mathrm{Y})$ & 0,845 \\
\hline
\end{tabular}

Sumber: Data diolah, 2019

Variabel semangat kerja dalam penelitian ini merupakan variabel terikat yang diukur dengan 5 pernyataan yang berhubungan dengan semangat kerja dari guru. Secara rinci hasil penelitian mengenai jawaban responden terhadap variabel semangat kerja dapat dilihat pada Tabel 4.

Hasil pada Tabel 4 menunjukan bahwa variabel semangat kerja memiliki nilai rata-rata dari 5 pernyataan yaitu sebesar 3,97 yang berarti dalam kategori tinggi, ini menunjukkan bahwa semangat kerja pada SMP Negeri 5 Denpasar dalam kondisi yang baik. Distribusi jawaban responden terhadap semangat kerja nilai rata-rata tertinggi sebesar 4,14 pada pernyataan "Jumlah kehadiran 
saya di dalam kelas sudah maksimal sesuai jam mengajar", sedangkan untuk nilai rata-rata terendah sebesar 3,71 pada pernyataan "Saya puas dengan pembagian kerja yang dilakukan".

Tabel 4.

Deskripsi Variabel Semangat Kerja

\begin{tabular}{|c|c|c|c|c|c|c|c|c|}
\hline \multirow[t]{2}{*}{ No } & \multirow[t]{2}{*}{ Pernyataan } & \multicolumn{5}{|c|}{$\begin{array}{c}\text { Frekuensi Jawaban } \\
\text { Responden }\end{array}$} & \multirow[t]{2}{*}{$\begin{array}{l}\text { Rata- } \\
\text { Rata }\end{array}$} & \multirow[t]{2}{*}{ Kriteria } \\
\hline & & STS & TS & $\mathbf{N}$ & $\mathbf{S}$ & SS & & \\
\hline 1 & $\begin{array}{l}\text { Jumlah kehadiran saya di } \\
\text { dalam kelas sudah maksimal } \\
\text { sesuai jam mengajar }\end{array}$ & 0 & 0 & 7 & 34 & 15 & 4,14 & Tinggi \\
\hline 2 & $\begin{array}{l}\text { Saya selalu menyelesaikan } \\
\text { jam mengajar tepat waktu } \\
\text { sesuai jadwal }\end{array}$ & 0 & 0 & 8 & 36 & 12 & 4,07 & Tinggi \\
\hline 3 & $\begin{array}{l}\text { Saya tidak meninggalkan } \\
\text { kelas saat jam mengajar } \\
\text { berlangsung }\end{array}$ & 0 & 0 & 15 & 28 & 13 & 3,96 & Tinggi \\
\hline 4 & $\begin{array}{l}\text { Saya mengajar sesuai dengan } \\
\text { instruksi kepala sekolah }\end{array}$ & 0 & 0 & 17 & 25 & 14 & 3,95 & Tinggi \\
\hline $\begin{array}{l}5 \\
\text { Rata }\end{array}$ & $\begin{array}{l}\text { Saya puas dengan pembagian } \\
\text { kerja yang dilakukan } \\
\text { ata keseluruhan variabel Semang }\end{array}$ & $\begin{array}{c}0 \\
\text { at Kerj }\end{array}$ & 0 & 24 & 24 & 8 & $\begin{array}{l}3,71 \\
3,97\end{array}$ & $\begin{array}{l}\text { Tinggi } \\
\text { Tinggi }\end{array}$ \\
\hline
\end{tabular}

Tabel 5.

Deskripsi Variabel Motivasi

\begin{tabular}{|c|c|c|c|c|c|c|c|c|}
\hline \multirow[t]{2}{*}{ No } & \multirow[t]{2}{*}{ Pernyataan } & \multicolumn{5}{|c|}{$\begin{array}{c}\text { Frekuensi Jawaban } \\
\text { Responden }\end{array}$} & \multirow[t]{2}{*}{$\begin{array}{l}\text { Rata- } \\
\text { Rata }\end{array}$} & \multirow[t]{2}{*}{ Kriteria } \\
\hline & & STS & TS & $\mathbf{N}$ & $\mathbf{S}$ & SS & & \\
\hline 1 & $\begin{array}{l}\text { Pendapatan yang saya } \\
\text { peroleh sudah mencukupi } \\
\text { kebutuhan hidup saat ini }\end{array}$ & 0 & 0 & 12 & 28 & 16 & 4,07 & Tinggi \\
\hline 2 & $\begin{array}{l}\text { Saya merasa aman dalam } \\
\text { bekerja karena sekolah } \\
\text { memperhatikan keselamatan } \\
\text { saya }\end{array}$ & 0 & 0 & 10 & 34 & 12 & 4,04 & Tinggi \\
\hline 3 & $\begin{array}{l}\text { Saya ikut terlibat dalam } \\
\text { kegiatan yang diadakan oleh } \\
\text { sekolah }\end{array}$ & 0 & 0 & 16 & 29 & 11 & 3,91 & Tinggi \\
\hline 4. & $\begin{array}{l}\text { Saya merasa termotivasi atas } \\
\text { penghargaan yang diberikan } \\
\text { oleh kepala sekolah }\end{array}$ & 0 & 0 & 14 & 24 & 18 & 4,07 & Tinggi \\
\hline 5. & $\begin{array}{l}\text { Kepala sekolah memberikan } \\
\text { kesempatan pelatihan kepada } \\
\text { guru untuk meningkatkan } \\
\text { kompetensi }\end{array}$ & 0 & 0 & 5 & 25 & 26 & 4,38 & Tinggi \\
\hline Rata & ata keseluruhan variabel Motivasi & & & & & & 4,09 & Tinggi \\
\hline
\end{tabular}


Variabel motivasi dalam penelitian ini merupakan variabel bebas yang diukur dengan 5 pernyataan yang berhubungan dengan motivasi. Secara rinci hasil penelitian mengenai jawaban responden terhadap variabel motivasi dapat dilihat pada Tabel 5. Hasil pada Tabel 5. menunjukan bahwa variabel motivasi memiliki nilai rata-rata dari 5 pernyataan yaitu sebesar 4,09 yang berarti dalam kategori tinggi, ini menunjukkan bahwa motivasi pada SMP Negeri 5 Denpasar dalam kondisi yang baik. Distribusi jawaban responden terhadap motivasi nilai rata-rata tertinggi sebesar 4,38 pada pernyataan "Kepala sekolah memberikan kesempatan pelatihan kepada guru untuk meningkatkan kompetensi", sedangkan untuk nilai rata-rata terendah sebesar 3,91 pada pernyataan "Saya ikut terlibat dalam kegiatan yang diadakan oleh sekolah".

Variabel komunikasi dalam penelitian ini merupakan variabel bebas yang diukur dengan 5 pernyataan yang berhubungan dengan komunikasi dari guru. Secara rinci hasil penelitian mengenai jawaban responden terhadap variabel komunikasi dapat dilihat pada Tabel 6. Hasil pada Tabel 6 menunjukan bahwa variabel komunikasi memiliki nilai rata-rata skor dari 5 pernyataan yaitu sebesar 3,94 yang berarti dalam kategori baik, ini menunjukkan bahwa komunikasi pada SMP Negeri 5 Denpasar dalam kondisi yang baik. Distribusi jawaban responden terhadap komunikasi dengan nilai rata-rata tertinggi sebesar 4,29 pada pernyataan "Saya berdiskusi dengan kepala sekolah mengenai masalah pekerjaan" sedangkan untuk nilai rata-rata terendah sebesar 3,48 pada pernyataan "Saya berkoordinasi dengan sesama guru dalam memecahkan masalah"

Tabel 6.

Deskripsi Variabel Komunikasi

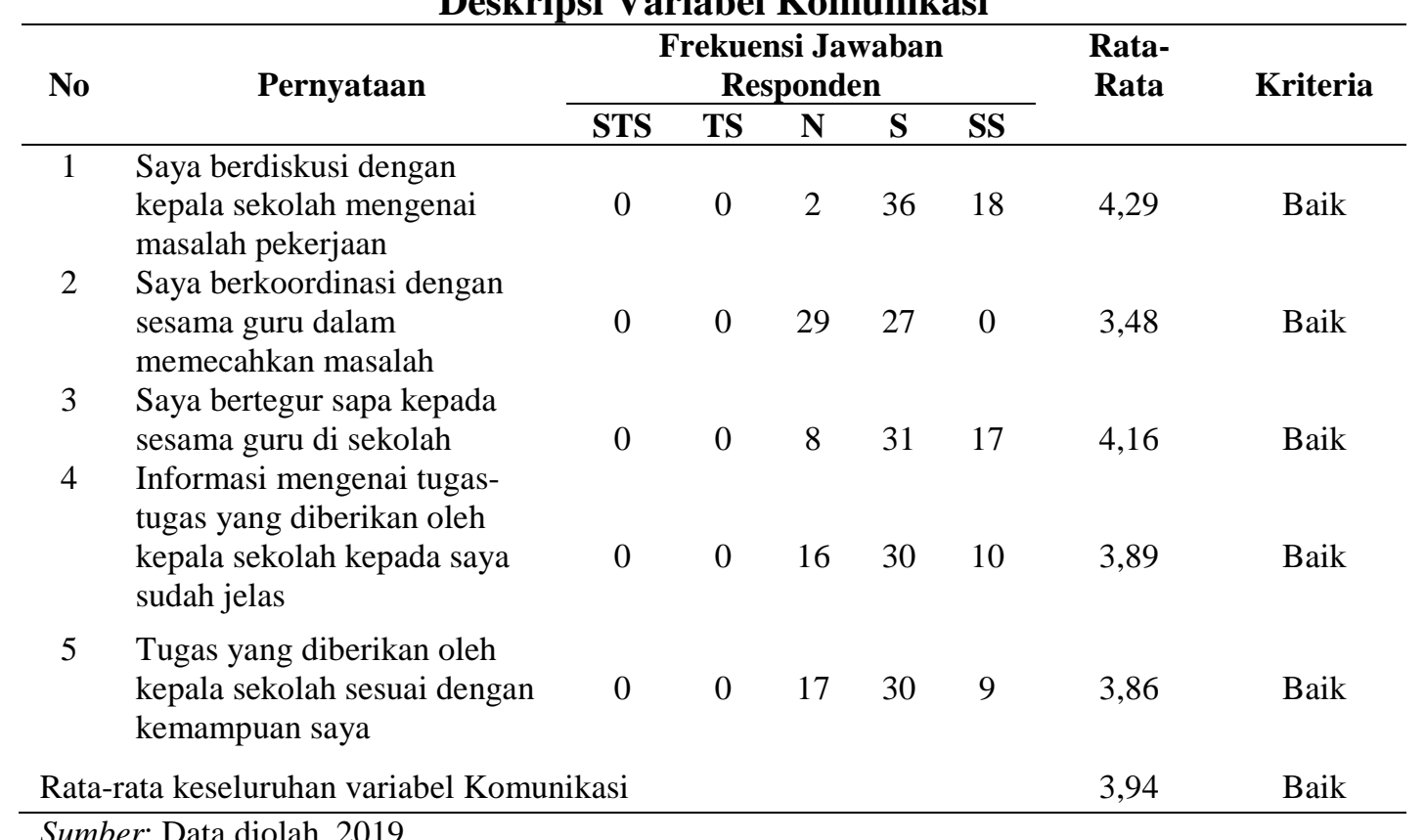

Sumber: Data diolah, 2019 
Tabel 7.

Deskripsi Variabel Lingkungan Kerja

\begin{tabular}{|c|c|c|c|c|c|c|c|c|}
\hline \multirow[t]{2}{*}{ No } & \multirow[t]{2}{*}{ Pernyataan } & \multicolumn{5}{|c|}{$\begin{array}{c}\text { Frekuensi Jawaban } \\
\text { Responden }\end{array}$} & \multirow[t]{2}{*}{$\begin{array}{l}\text { Rata- } \\
\text { Rata }\end{array}$} & \multirow[t]{2}{*}{ Kriteria } \\
\hline & & STS & TS & $\mathbf{N}$ & $\mathbf{S}$ & SS & & \\
\hline 1 & $\begin{array}{l}\text { Suasana ruang kelas tempat } \\
\text { mengajar cukup nyaman }\end{array}$ & 0 & 0 & 21 & 28 & 7 & 3,75 & Baik \\
\hline 2 & $\begin{array}{l}\text { Saya beradaptasi dengan suhu } \\
\text { udara/temperature di sekolah }\end{array}$ & 0 & 0 & 17 & 31 & 8 & 3,84 & Baik \\
\hline 3 & $\begin{array}{l}\text { Fasilitas ruang kelas sudah } \\
\text { lengkap }\end{array}$ & 0 & 1 & 13 & 25 & 7 & 3,68 & Baik \\
\hline 4 & $\begin{array}{l}\text { Hubungan kekrabatan saya } \\
\text { dengan sesama rekan guru } \\
\text { terjalin dengan baik }\end{array}$ & 0 & 0 & 10 & 30 & 16 & 4,11 & Baik \\
\hline 5 & $\begin{array}{l}\text { Keamanan di sekolah } \\
\text { membuat saya bekerja dengan } \\
\text { nyaman }\end{array}$ & 0 & 0 & 14 & 24 & 18 & 4,07 & Baik \\
\hline Rata & ata keseluruhan variabel Lingk & $\operatorname{gan} \mathrm{K}$ & & & & & 3,89 & Baik \\
\hline
\end{tabular}

Sumber: Data diolah, 2019

Hasil pada Tabel 7. menunjukan bahwa variabel lingkungan kerja memiliki nilai rata-rata skor dari 5 pernyataan yaitu sebesar 3,89 yang berarti dalam kategori baik, ini menunjukkan bahwa lingkungan kerja pada SMP Negeri 5 Denpasar dalam kondisi yang baik. Distribusi jawaban responden terhadap lingkungan kerja dengan nilai rata-rata tertinggi sebesar 4,11 pada pernyataan "Hubungan kekrabatan saya dengan sesama rekan guru terjalin dengan baik", sedangkan untuk nilai rata-rata terendah sebesar 3,68 pada pernyataan "Fasilitas ruang kelas sudah lengkap".

Tabel 8.

Hasil Uji Analisis Regresi Linier Berganda

\begin{tabular}{|c|c|c|c|c|c|}
\hline \multirow[t]{2}{*}{ Model } & \multicolumn{2}{|c|}{$\begin{array}{c}\text { Unstandardized } \\
\text { Coefficients }\end{array}$} & \multirow{2}{*}{$\begin{array}{c}\begin{array}{c}\text { Standardized } \\
\text { Coefficients }\end{array} \\
\text { Beta } \\
\end{array}$} & \multirow[t]{2}{*}{$\mathbf{T}$} & \multirow[t]{2}{*}{ Sig. } \\
\hline & $\mathbf{B}$ & Std. Error & & & \\
\hline 1 (Constant $)$ & .143 & .188 & & .758 & .452 \\
\hline Motivasi & .361 & .096 & .379 & 3.766 & .000 \\
\hline Komunikasi & .305 & .104 & .285 & 2.917 & .005 \\
\hline Lingkungan Kerja & .295 & .099 & .327 & 2.967 & .005 \\
\hline$R$ Square & & & & & .903 \\
\hline F Statistik & & & & & 162.141 \\
\hline Signifikansi & & & & & 0.000 \\
\hline
\end{tabular}

Berdasarkan hasil analisis regresi linier berganda seperti yang ditunjukkan pada Tabel 8, maka persamaan regresinya adalah sebagai berikut.

$\mathrm{Y}=0,143+0,361 \mathrm{X}_{1}+0,305 \mathrm{X}_{2}+0,295 \mathrm{X}_{3}$

Persamaan regresi linier berganda di atas diketahui bahwa koefisien regresi dari variabel motivasi sebesar 0,361 dan bertanda positif yang berarti apabila terjadi peningkatan sebesar satu satuan, maka akan menyebabkan meningkatnya semangat kerja sebesar 0,361 dengan asumsi variabel yang lain dalampersamaan ini konstan. Persamaan regresi linier berganda di atas 
diketahui bahwa koefisien regresi dari variabel komunikasi sebesar 0,305 dan bertanda positif yang berarti bahwa apabila terjadi peningkatan sebesar satu satuan, maka akan menyebabkan meningkatknya semangat kerja sebesar 0,305 dengan asumsi variabel yang lain dalam persamaan ini konstan. Persamaan regresi linier berganda di atas diketahui bahwa koefisien regresi dari variabel lingkungankerja sebesar 0,295 dan bertanda positif yang berarti bahwa apabila terjadi peningkatan sebesar satu satuan, maka akan menyebabkan meningkatknya semangat kerja sebesar 0,295 dengan asumsi variabel yang lain dalam persamaan ini konstan.

Tabel 9.

Hasil Uji Normalitas

\begin{tabular}{cc}
\hline & Unstandardized Residual \\
\hline $\mathrm{N}$ & 56 \\
Kolmogorov-Smirnov $Z$ & 0,831 \\
Asymp. Sig. (2-tailed) & 0,494 \\
\hline
\end{tabular}

Sumber: Data diolah, 2019

Berdasarkan hasil analisis didapat nilai signifikansi sebesar 0,494 seperti yang ditunjukkan oleh Tabel 9. Karena nilai signifikansi uji KolmogrovSmirnov lebih dari 0,05 maka dapat disimpulkan bahwa model persamaan regresi tersebut berdistribusi normal.

Tabel 10.

Hasil Uji Multikolinearitas

\begin{tabular}{lcc}
\hline & \multicolumn{2}{c}{ Colinearity Statistic } \\
\cline { 2 - 3 } \multicolumn{1}{c}{ Model } & Tolerance & VIF \\
\hline Motivasi & 0.184 & 5.450 \\
Komunikasi & 0.194 & 5.150 \\
Lingkungan Kerja & 0.153 & 6.549 \\
\hline
\end{tabular}

Sumber: Data diolah, 2019

Berdasarkan Tabel 10. dapat dilihat bahwa nilai tolerance dan varianceinflation factor (VIF) dari seluruh variabel tersebut menunjukkan bahwa nilai tolerance untuk setiap variabel lebih besar dari 0,10 dan nilai variance inflation factor (VIF) lebih kecil dari 10 yang berarti model persamaan regresi bebas dari multikolinearitas.

Tabel 11.

Hasil Uji Heterokedastisitas

\begin{tabular}{|c|c|c|c|c|c|}
\hline \multirow[t]{2}{*}{ Model } & \multicolumn{2}{|c|}{$\begin{array}{l}\text { Unstandardized } \\
\text { Coefficients }\end{array}$} & \multirow{2}{*}{$\begin{array}{c}\begin{array}{c}\text { Standardized } \\
\text { Coefficients }\end{array} \\
\text { Beta }\end{array}$} & \multirow[b]{2}{*}{$\mathbf{T}$} & \multirow[b]{2}{*}{ Sig. } \\
\hline & B & Std. Error & & & \\
\hline (Constant) & .004 & .113 & & .033 & .973 \\
\hline Motivasi & -.041 & .058 & -.225 & -.712 & .480 \\
\hline Komunikasi & .032 & .063 & .157 & .512 & .611 \\
\hline Lingkungan Kerja & .043 & .060 & -.248 & .715 & .478 \\
\hline
\end{tabular}


Pada Tabel 11. dapat dilihat bahwa nilai signifkansi dari variabel motivasi sebesar 0,480, komunikasi sebesar 0,611 dan lingkungan kerja sebesar 0,478. Nilai tersebut lebih besar dari 0,05 yang berarti tidak terdapat pengaruh antara variabel bebas terhadap absolute residual. Dengan demikian, model yang dibuat tidak mengandung gejala heterokedastisitas.

Tabel 12.

Hasil Uji Kelayakan Model (Uji F)

\begin{tabular}{lrrrrr}
\hline Model & Sum of Squares & Df & Mean Square & F & Sig. \\
\hline 1 Regression & 13.860 & 3 & 4.620 & 162.141 & $0.000^{\mathrm{a}}$ \\
Residual & 1.482 & 52 & 0.028 & & \\
Total & 15.342 & 55 & & & \\
\hline
\end{tabular}

Sumber: Data diolah, 2019

Berdasarkan Tabel 12. menunjukkan nilai Sig. sebesar $0,000<0,05$. Hasil ini mempunyai arti bahwa motivasi komunikasi, dan lingkungan kerja berpengaruh signifikan secara serempak atau bersama-bersama terhadap semangat kerja, sehingga penelitian ini dapat diikatakan memenuhi uji kelayakan model atau model penelitian ini dinyatakan layak digunakan sebagai model regresi.

Tabel 13. menunjukan bahwa besarnya nilai $R$ Square sebesar 0,903 yang diartikan bahwa sebesar 90 persen variasi semangat kerja dipengaruhi oleh variasi motivasi, komunikasi, dan lingkungan kerja secara bersama, sedangkan sisanya sebesar 10 persen dijelaskan oleh faktor lain yang tidak dianalisis dalam model ini.

Tabel 13.

Hasil Analisis Koefisien Determinasi $\left(\mathbf{R}^{2}\right)$

\begin{tabular}{lcccc}
\hline Model & $\mathbf{R}$ & $\boldsymbol{R}$ Square & $\begin{array}{c}\text { Adjusted } \boldsymbol{R} \\
\text { Square }\end{array}$ & $\begin{array}{c}\text { Std. } \text { Error of the } \\
\text { Estimate }\end{array}$ \\
\hline 1 & $.950^{\mathrm{a}}$ & .903 & .898 & 1.688 \\
\hline Sumber: Data diolah, 2019 & & \multicolumn{4}{l}{}
\end{tabular}

Analisis pengaruh motivasi terhadap semangat kerja diperoleh nilai signifikansi sebesar 0,000 dengan nilai koefisien regresi positif sebesar 0,361. Nilai signifikansi $0,000<0,05$ mengindikasikan bahwa $\mathrm{H}_{0}$ ditolak dan $\mathrm{H}_{1}$ diterima. Hasil ini mempunyai arti bahwa motivasi berpengaruh positif dan signifikan terhadap semangat kerja. Analisis pengaruh komunikasi terhadap semangat kerja diperoleh nilai signifikansi sebesar 0,005 dengan nilai koefisien regresi positif sebesar 0,305 . Nilai signifikansi $0,005<0,05$ mengindikasikan bahwa $\mathrm{H}_{\square}$ ditolak dan $\mathrm{H}_{2}$ diterima. Hasil ini mempunyai arti bahwa komunikasi berpengaruh positif dan signifikan terhadap semangat kerja. Analisis pengaruh lingkungan kerja terhadap semangat kerja diperoleh nilai signifikansi sebesar 0,005 dengan nilai koefisien regresi positif sebesar 0,295. Nilai signifikansi 0,005 $<0,05$ mengindikasikan bahwa $\mathrm{H}_{\square}$ ditolak dan $\mathrm{H}_{3}$ diterima. Hasil ini mempunyai arti bahwa lingkungan kerja berpengaruh positif dan signifikan terhadap semangat kerja. 
Hasil penelitian menunjukkan bahwa motivasi berpengaruh positif dan signifikan terhadap semangat kerja guru. Hal ini mengindikasikan bahwa motivasi guru di SMP Negeri 5 Denpasar dalam kondisi baik, karena pendapatan yang diperoleh guru sudah mencukupi kebutuhan hidup, sekolah memperhatikan keselamatan guru yang dapat memotivasi guru untuk bekerja, guru ikut terlibat dalam kegiatan yang diadakan oleh sekolah, guru merasa termotivasi atas penghargaan yang diberikan oleh kepala sekolah, dan setiap guru diberikan kesempatan untuk meningkatkan kompetensinya. Hal ini sesuai dengan hipotesis satu bahwa motivasi berpengaruh positif dan signifikan terhadap semangat kerja guru. Semakin tinggi motivasi yang dimiliki guru maka akan semakin meningkat semangat kerja yang dimiliki guru. Hal ini sejalan dengan hasil penelitian yang dilakukan oleh Putra \& Suwandana (2019) menyebutkan bahwa motivasi berpengaruh positif dan signifikan terhadap semangat kerja. Begitu juga dengan penelitian yang dilakukan Cahyani \& Mujiati (2019) menyatakan bahwa motivasi memiliki pengaruh positif dan signifikan terhadap semangat kerja.

Hasil penelitian menunjukkan bahwa komunikasi berpengaruh positif dan signifikan terhadap semangat kerja guru. Hal ini mengindikasikan bahwa komunikasi yang dilakukan oleh guru SMP Negeri 5 Denpasar dalam kondisi baik, karena guru SMP Negeri 5 Denpasar telah mampu mendiskusikan kepada kepala sekolah dan dengan sesama guru mengenai masalah pekerjaan, berkoordinasi dengan sesama guru dalam memecahkan masalah, bertegur sapa kepada guru lainnya di sekolah, memberikan informasi kepada rekan guru yang berkaitan dengan tugas-tugas di sekolah, dan segala informasi mengenai tugastugas yang diberikan oleh kepala sekolah sudah bisa dimengerti oleh guru.

Hal ini sesuai dengan hipotesis dua bahwa komunikasi berpengaruh positif dan signifikan terhadap semangat kerja guru. Semakin baik komunikasi di dalam sekolah maka semangat kerja guru akan meningkat. Hal ini sejalan dengan hasil penelitian yang dilakukan oleh Yasa \& Wibawa (2015) dan Jannah et al. (2018) yang menyatakan bahwa komunikasi berpengaruh positif dan signifikan terhadap semangat kerja. Selanjutnya penelitian yang dilakukan oleh Widani (2018) menunjukkan bahwa komunikasi berpengaruh positif dan signifikan terhadap semangat kerja, hal yang sama juga disimpulkan oleh Arianto (2015) yang menyatakan bahwa komunikasi berpengaruh positif dan signifikan terhadap semangat kerja. Serta pada penelitian Utamajaya \& Ayu Sriathi (2015) menemukan bahwa komunikasi berpengaruh signifikan terhadap semangat kerja.

Hasil penelitian menunjukkan bahwa lingkungan kerja berpengaruh positif dan signifikan terhadap semangat kerja guru. Hal ini mengindikasikan bahwa lingkungan kerja di SMP Negeri 5 Denpasar dalam kondisi baik, karena sekolah sudah memperhatikan betul lingkungan kerja disekitar. Hal ini sesuai dengan hipotesis tiga bahwa lingkungan kerja berpengaruh positif dan signifikan terhadap semangat kerja guru. Hal ini sejalan dengan hasil penelitian yang dilakukan oleh Fitri (2015)menyatakan bahwa lingkungan kerja berpengaruh positif dan signifikan terhadap semangat kerja. Hal ini juga mendukung penelitian yang dilakukan oleh Jayaet al. (2017) yang menyatakan bahwa lingkungan kerja berpengaruh positif dan signifikan terhadap semangat kerja. 
Dalam hal motivasi, guru SMP Negeri 5 Denpasar merasakan adanya motivasi yang tinggi antara guru dengan sekolah. Hal ini menimbulkan adanya tingkat semangat kerja yang tinggi dalam sekolah, karena dengan adanya motivasi yang tinggi, sekolah akan mampu menciptakan sebuah kerjasama yang baik antar guru sehingga guru mampu meningkatkan semangat dalam bekerja. Oleh karena itu, pihak sekolah harus menjaga dan memperhatikan motivasi yang diberikan kepada guru. Dalam hal berkomunikasi, guru SMP Negeri 5 Denpasar merasa nyaman dengan komunikasi antara kepala sekolah maupun guru lainnya, sehingga guru mampu meningkatkan semangat kerja. Oleh karena itu, pihak sekolah harus mampu mempertahankan komunikasi yang dimiliki guru, karena ketika komunikasi berhenti, kegiatan sekolah dan kegiatan individual tidak akan terkoordinasi dalam suatu orgnisasi. Terkait dengan lingkungan kerja, guru SMP Negeri 5 Denpasar merasa nyaman dan aman dalam bekerja dikarenakan sekolah mampu menyediakan lingkungan kerja yang nyaman. Oleh karena itu, sekolah harus mampu mempertahankan keadaan dan situasi lingkungan kerja untuk meningkatkan semangat kerja guru dan demi mencapai tujuan sekolah.

\section{SIMPULAN}

Motivasi memiliki pengaruh positif dan signifikan terhadap semangat kerja guru di SMP Negeri 5 Denpasar. Hal ini menunjukkan semakin tinggi motivasi yang dimiliki guru maka akan semakin tinggi semangat kerja yang dimiliki guru SMP Negeri 5 Denpasar. Komunikasi memiliki pengaruh positif dan signifikan terhadap semangat kerja guru di SMP Negeri 5 Denpasar. Hal ini menunjukkan bahwa ketika komunikasi diterapkan dengan baik maka semangat kerja guru juga akan meningkat. Lingkungan kerja memiliki pengaruh positif dan signifikan terhadap semangat kerja guru di SMP Negeri 5 Denpasar. Hal ini menunjukkan bahwa semakin baik kondisi lingkungan kerja maka akan semakin meningkatkan semangat kerja guru di SMP Negeri 5 Denpasar.

Pihak sekolah perlu memperhatikan lagi indikator motivasi yang nilai rataratanya berada dibawah nilai rata-rata variabel. Nilai rata-rata tersebut dengan indikator "saya ikut terlibat dalam kegiatan yang diadakan oleh sekolah". Sebaiknya kepala sekolah lebih memberikan arahan lagi agar semua guru ikut terlibat dalam kegiatan sekolah. Pihak SMP Negeri 5 Denpasar sebaiknya memperhatikan kembali komunikasi guru dalam hal "saya berkoordinasi dengan sesama guru dalam memecahkan masalah" . Jika sesama guru tidak berkomunikasi dan berkoordinasi terkait masalah yang ada, maka tujuan sekolah tidak akan tercapai. Pihak SMP Negeri 5 Denpasar sebaiknya lebih memperhatikan lagi fasilitas-fasilitas yang ada di ruang kelas, karena hal tersebut berdasarkan rata-rata skor mengenai tanggapan yang diberikan guru mendapatkan skor 3,68 nilai tersebut rata-ratanya berada dibawah nilai rata-rata variabel. Jika fasilitas di dalam ruang kelas lengkap, makaproses belajar mengajar akan berjalan dengan baik dan semangat kerja guru dalam mengajar akan meningkat. 


\section{REFERENSI}

Adnyani, N. P. A. N., \& Surya, I. B. K. (2019). Peran Mediasi Motivasi Kerja Pada Pengaruh Kompensasi Terhadap Semangat Kerja Di Bumdes Udaka Dawan. E-Jurnal Manajemen Universitas Udayana, 8(10), 6059-6078.

Ahmed, I., M.M., N., Iqbal, N., Ali, I., Shaukat, Z., \& Usman, A. (2016). Effects Of Motivational Factors On Employees Job Satifaction A Case Study Of University Of The Punjab,Pakistan. International Journal Of Business and Management, 5(3), 70-80.

Arianto, D. A. N. (2015). Pengaruh Komunikasi Organisasi Dan Kompensasi Terhadap Semangat Kerja Karyawan. Jurnal Economia, 11(2), 177-185.

Arunchand, C. H., \& Ramanathan, N. H. (2016). Organizational Culture and Employee Morale: A Public Sector Enterprise Experience. Journal of Strategic Human Resources Management, 2(1), 1-8.

Cahyani, N. M. D. M., \& Mujiati, N. W. (2019). Pengaruh Lingkungan Kerja, Motivasi, Dan Kompensasi Terhadap Semangat Kerja. E-Jurnal Manajemen Universitas Udayana, 8(5), 3193-3219.

Darmawan, I. G. W., \& Wibawa, I. M. A. (2019). Pengaruh Kompensasi Finansial, Lingkungan Kerja Non Fisik, Dan Komitmen Organisasional Terhadap Semangat Kerja Karyawan. E-Jurnal Manajemen Universitas Udayana, 8(8), 5118-5138.

Devina, U., \& Anu, G. (2015). Morale, Welfare measures, Job Satisfaction: The Key Mantras for Gaining Competitive Edge. International Journal of Physical and Social Sciences, 2(7), 80-94.

Dewi, N. P. I. C., \& Dewi, A. A. S. K. (2019). Pengaruh Motivasi, Komunikasi, dan Lingkungan Kerja Fisik Terhadap Semangat Kerja Karyawan PT. Ayu Sari Pertiwi. E-Jurnal Manajemen Universitas Udayana, 8(12), 7093-7114.

Febriani, M., \& Supartha, I. W. G. (2019). Pengaruh Komitmen Organisasional, Gaya Kepemimpinan Transformasional, dan Kompensasi Finansial Terhadap Semangat Kerja Karyawan Perusahaan Logistik. E-Jurnal Manajemen Universitas Udayana, 4(8), 2267-2296.

Femi, A. F. (2014). The Impact Of Communication on Worker's Performance in Selected Organisations in Lagos State, Nigeria. IOSR Journal Of Humanities and Social Science (IOSR-JHSS), 19(8), 75-82.

Fitri, Y. (2015). Effect of compensation and working environment against job spirit employeein Indrapura Hotel Pekanbaru. Journal of Management, 2(1), 
$1-13$.

Ghaffari, S., Shah, I. M., Burgoyne, J., Nazri, M., \& Salleh, J. R. (2017). The Influence of Motivation on Job Performance: A Case Study at Universiti Teknologi Malaysia. Australian Journal Of Basic And Applied Sciences, 11(4), 92-99.

Gresida, N. W. P., \& Utama, I. W. M. (2019). Pengaruh Komunikasi, Motivasi, dan Lingkungan Kerja Terhadap Disiplin Kerja Karyawan. E-Jurnal Manajemen Univeristas Udayana, 8(10), 5928-5946.

Hasanah, R., \& Kasmiruddin. (2016). Pengaruh Lingkungan Kerja terhadap Semangat Kerja Karyawan Bagian Service Pada PT.United Tractor TBK Pekan Baru. JOM FISIP, 3(1), 1-15.

Inbar, N. R. D., Astuti, E. S., \& Sulistyo, M. C. W. (2018). Pengaruh Lingkungan Kerja Terhadap Disiplin Kerja Dan Semangat Kerja Karyawan (Studi Pada Karyawan PDAM Kota Malang). Jurnal Administrasi Bisnis (JAB), 58(2), 84-92.

Jain, R., \& Kaur, S. (2016). Impact of Work Environment on Job Satisfaction. International Journal of Scientific and Research Publications, 1(1), 22503153.

Jannah, N. B., Sujana, I. N., \& Zukhri, A. (2018). Pengaruh Lingkungan Kerja Fisik Dan Komunikasi Terhadap Semangat Kerja Karyawan Pada PT. Bali Maya Permai Negara Jembrana. Jurnal Pendidikan Ekonomi Undiksha, 10(1), 316-325.

Jaya, I. G. M. K., Sudibya, I. G. A., \& Sudharma, I. N. (2017). Pengaruh Lingkungan Kerja, Dan Motivasi Serta Kompensasi Terhadap Semangat Kerja Pegawa Dinas Kesehatan Kabupaten Tabanan. E-Jurnal Ekonomi Dan Bisnis Unud, 6(2), 2337-3067.

Karademir, T., Karakaya, E. Y., \& Sirin, Y. (2016). Physical Education Teachers Preceptions of Organizational Culture and Communications in Educational Instituitions. Journal of Physical Education and Sport, 14(4), 637-642.

Maduka, C. E., \& Okafor, O. (2015). Effect of Motivation on Employee Productivity: A Study Of Manufacturing Companies in Newi. International Journal of Managerial Studies and Research (IJMSR), 2(7), 137-147.

Maslichah, N. I., \& Hidayat, K. (2017). Pengaruh Work-life Balance dan Lingkungan Kerja Terhadap Kepuasan Kerja Karyawan. Jurnal Administrasi Bisnis, 49(1), 60-68. 
Mudasir, Adiswisastra, Y., Hubeis, M., \& Sulistyani, D. (2015). The Effect of Leadership, Communication, and Discipline of the Population Administration Services in Palembang. Scientific Research Journal (SCIRJ), 2(8), 28-34.

Nuraini., Indarti, S., \& Marzolina. (2015). Pengaruh lingkungan kerja dan motivasi terhadap produktivitas kerja karyawan pada PT. Perkebunan Nusantara V Cabang Kebun Inti Kecamatan Tapung Kabupaten Kampar. Jom Fekon, 2(1), 1-15.

Octaviani, L. P., \& Suana, I. W. (2019). Pengaruh Motivasi, Kompensasi, Dan Lingkungan Kerja Fisik Terhadap Semangat Kerja Karyawan Bello Desain Di Singaraja. E-Jurnal Manajemen Universitas Udayana, 8(12), 7115-7133.

Ololube, P. N. (2015). Teachers Job Satisfaction and Motivation for School Effectiveness: An Assessment. International Journal of Helsinki Finlandia University, 18(9), 1-19.

Omollo, P. A. (2015). Effect of motivation on employee performance of commercial banks in Kenya: A case study of Kenya Commercial Bank in Migori Country. International Journal of Human Resource Studies, 5(2), 87103.

Putra, P. W. G. S., \& Suwandana, I. G. M. (2019). Pengaruh Motivasi, Gaya Kepemimpinan Transformasional Dan Lingkungan Kerja Fisik Terhadap Semangat Kerja Pegawai Bappeda Litbang Provinsi Bali. E-Jurnal Manajemen Universitas Udayana, 8(5), 2973-2998.

Riyanto, S., Sutrisno, A., \& Ali, H. (2017). The Impact of Working Motivation and Working Environment on Employees Performance in Indonesian Stock Exchange. Econ Jurnals, 7(3), 342-348.

Shidhaye, R. V., Divekar, D. S., Goel, G., \& Shidhaye, R. (2015). Influence Of Working Condition On Job Satisfaction In Indian Anesthesiologists: A Cross Sectional Survey. Indian Institute Of Public Health Journal, 15(1), 30-37.

Shonubi, A. O., \& Akintaro, A. A. (2016). The Impact of Effective Communication On Organizational Performance. The International Journal of Social Sciences and Humanities Invention, 3(3), 1904-1914.

Sumampouw, E. S., Sumayku, S. M., \& Kalangi, J. A. F. (2016). Pengaruh Kompensasi dan Motivasi Terhadap Semangat Kerja Karyawan Pada PT. Bank Tabungan Negara, TBK. Jurnal Administrasi Bisnis (JAB), 4(1), 1-9.

Swandono, S. (2016). Pengaruh Lingkungan Kerja Terhadap Produktivitas Kinerja Karyawan (Bagian Produksi Minyak Kelapa Sawit PT. Mitra Unggul 
Pusaka Segati Pelalawan Riau). JOM FISIP, 3(2), 1-13.

Syamsudin, \& Bachtiar, T. (2018). Pengaruh Lingkungan Kerja Dan Motivasi Terhadap Semangat Kerja Divisi Produksi Karyawan Pada PT. Utama Gas Multi Perkasa Cabang Serang. Jurnal Sains Manajemen, 4(1), 36-45.

Syamsuri, P. (2017). The Influence of Organizational Culture, Work Motivation, and Organizational Commitment to the Performance of Principals. Indonesian Journal of Educational Review, 4(1), 1-8.

Tiwari, U. (2015). A Study On Employee Morale And Its Impact On Employee Efficiency At Jaypee Cement Plant Rewa (M.P.). International Monthly Refreed Journal of Research in Management and Technology, 3(11), 1-7.

Utamajaya, I. D. G. A. P., \& Ayu Sriathi, A. A. (2015). Pengaruh Motivasi, Komunikasi, Serta Lingkungan Kerja Fisik Terhadap Semangat Kerja Karyawan Pada Fuji Jaya Motor Gianyar. E-Jurnal Manajemen Universitas Udayana, 4(6), 1504-1524.

Widani, N. L. S. (2018). Pengaruh Kompensasi Dan Komunikasi Terhadap Semangat Kerja Karyawan Pada Hotel Puri Dajuma Resort. Jurnal Pendidikan Ekonomi Undiksha, 10(1), 2599-1418.

Yasa, I. K. M. S., \& Wibawa, I. M. A. (2015). Pengaruh Kompensasi Finansial, Komunikasi Dan Lingkungan Kerja Fisik Terhadap Semangat Kerja Karyawan. E-Jurnal Manajemen Universitas Udayana, 4(3), 750-763.

Zahari, M. (2015). Pengaruh Motivasi Terhadap Disiplin Kerja Pegawai pada Dinas Perindustrian dan Perdagangan Provinsi Jambi. EKSIS: Jurnal Ilmiah Ekonomi Dan Bisnis, 6(1), 47-57. 